\title{
PRO-CONSTITUTIONAL INTERPRETATION OF STATUTES. A FEW REMARKS RELATED TO THE DISPUTE ABOUT JUDICIAL ACTIVISM
}

\author{
Hubert Kaczmarczyk*
}

\begin{abstract}
The article presents an opinion in the discussion on the limits of judicial activism. The active attitude of judges in the law-making process according to the so-called concept of 'pro-constitutional interpretation of the law' can be observed more and more often. While we may agree with the view that the role of a judge is to pronounce a fair verdict based on the applicable law and judges may give meaning to statutory provisions supplemented with an axiology of the Constitution, the problem appears with particular sharpness when such a pro-constitutional interpretation leads to a specific application of the provisions contra legem.
\end{abstract}

Keywords: judicial activism, limits of legal interpretation, pro-constitutional interpretation of statutes

\section{INTRODUCTION. OUTLINE OF THE ISSUES OF JUDICIAL ACTIVISM}

The dispute related to the role of the judge in the process of interpretation of the law has a long tradition. It has been observed an increase in interest in judicature and its enormous impact on a democratic society for

Dr. Hubert Kaczmarczyk, Teaching Associate, Faculty of Law and Social Sciences, Jan Kochanowski University in Kielce; correspondence address: ul. Uniwersytecka 15, 25-406 Kielce, Poland; e-mail: hubert.kaczmarczyk@ujk.edu.pl; https://orcid.org/ 0000-0002-0075-9899. 
several decades. At present, the approval of judicial activism can be found within the derivative category of the theory of interpretation of law, which means that the act itself is only a legal text, and therefore it is a semi-product which only after processing of interpretation (interpretation) by a lawyer and creation of derived rules of proper behavior becomes the law ${ }^{1}$. In practice, judicial activism has been inseparably linked with the judge as a representative of the judiciary from the very beginning. With the passing of time and the victory of the positive law ideology, activism was limited but never lost its importance. Courts have been still forced to evaluate, assign normative content to general clauses and take into account in their jurisprudence - especially in the case of constitutional tribunals - political expectations.

The term 'judicial activism' appeared for the first time in the literature in 1947 and from the very beginning it has a pejorative character given by Arthur Schlesinger Jr. in his work, criticizing the attitude of some judges of the US Supreme Court in relation to the interference of the Supreme Court in economic reforms in the frame of the so-called New Deal (a legislative agenda initiated by President Franklin Delano Roosevelt) ${ }^{2}$. The Supreme Court was criticized again when it was headed by Judge Earl Warren (1953-1969). It was then accused of introducing social reforms in violation of previous precedents and of changing the judicial interpretation of the constitution and statutes. This attitude met with strong opposition and caused public interest to such an extent that Richard Nixon, as the candidate of the opposition in the presidential elections, announced the fight against activism as the main goal of his presidency and propagated the slogan: 'judicial activism - a strict interpretation of the constitution' as his election $\operatorname{slogan}^{3}$.

1 More information on derivative concept of interpretation: Maciej Zieliński and Marek Zirk-Sadowski, "Klaryfikacyjność i derywacyjność w integrowaniu polskich teorii wykładni prawa," Ruch Prawniczy, Ekonomiczny i Socjologiczny 2 (2011): 99-111 and Maciej Zieliński, "Derywacyjna koncepcja wykładni jako koncepcja zintegrowana," Ruch Prawniczy, Ekonomiczny i Socjologiczny 3 (2006): 93-101.

2 See: Arthur M. Schlesinger Jr., “The Supreme Court," XXXV Fortune 73 (January 1947).

3 Paweł Kuczma, "O aktywizmie sędziowskim," Zeszyty Naukowe Uczelni Jana Wyżykowskiego. Studia z Nauk Spotecznych 9 (2016): 188. 
Lech Morawski defines judicial activism as a situation in which a judge makes a decision not determined by legal provisions, and makes his own choice, and this choice is not made by the legislator. In other words, it can be said that an 'activist' judge is the one who, by returning verdict begins to replace the legislator ${ }^{4}$. On the other hand, the activism of the supreme court or the Constitutional Tribunal is understood by Bogusław Banaszak as going this judicial authority beyond the adjudication in specific cases and participation in the broadly understood solving of social problems or shaping the concept of the state. He thinks that judicial activism is one of the factors which has impact on the frequency of constitutional amendments. In the situation where the court which interprets the norms of the constitution is more active, it is easier to avoid constitutional amendments, because instead of introducing a formal amendment, it is possible, through judicature to give the provisions of the Constitution new meaning 5 .

The problem of judicial activism can also be analyzed from the perspective of civil disobedience (in this case, judicial disobedience, as Jerzy Zajadło describes in his article, judicial disobedience ${ }^{6}$. Of course, Jerzy Zajadło thinks, that there is a very important difference between civil and judicial disobedience. In the first case, it is a deliberate breach of the law in the broadly understood sense of the public interest and a simultaneous readiness to bear responsibility for the breach of law. In the second case, the judge must seek a solution for the situation under the applicable law - either by appropriate interpretation of the law to take an equitable decision (individual dimension), or by direct reference to the Constitution to defend a constitutional axiology including the principle of separation of powers (institutional dimension). There is, however, a certain paradox here - while civil disobedience is, in the very nature of things, an attitude which is inconsistent with the law, but judicial disobedience is a strictly legalistic attitude which aim is the protection of the axiology of the Constitution ${ }^{7}$.

4 Lech Morawski, “Zasada trójpodziału władzy. Trybunał Konstytucyjny i aktywizm sędziowski,” Przegląd Sejmowy 4 (93) (2009): 65.

5 Bogusław Banaszak, "Aktywizm orzeczniczy Trybunału Konstytucyjnego," Przeglad Sejmowy 4 (93) (2009): 75.

6 Jerzy Zajadło, “Nieposłuszeństwo sędziowskie,” Państwo i Prawo 1 (2016): 18-39.

7 Zajadło, "Nieposłuszeństwo sędziowskie," 36-37. 
While law and order makes social life predictable and provides certainty as to the possibility of meeting common expectations, the answer to the question related to the above-mentioned doubts about the independence of judges, namely what is the social function of the separation of legislation and judicature is less obvious. In other words, what problem does this chapter solve? This differentiation causes a fundamental limitation and, at the same time, a decision-making criterion for both parties: the judge and the legislator: 'The judge applies acts and follows the legislator's instructions. On the other hand, the legislator "would have disappeared into the wide blue yonder" (Esser) if he had not taken into account that (and how) the new acts can be integrated into the overall decision-making premises of the courts' ${ }^{8}$. However, it is worth to notice a certain paradox and a threat in the formalistic or, in other words, positivist conception of the judge, who is only 'the mouth of the law', following the legislator's instructions. In fact, adoption of such attitude causes that a judge becomes only a state official and applicable legal order gives him the opportunity to make decisions concerning the choice of legal consequences indicated by a legal provision, because even in such case it is difficult to assume that these consequences are indicated by legal norms, since the norm is the result of interpretation not only of provisions, but also principles and adoption of an appropriate axiological perspective. In such a model of discretion, the judge, and as a consequence, the court, are deprived of the possibility of meting out justice. It should be expressed and understood in this way, because a judge has no opportunity to reconcile law and justice in all those cases where the law clearly comes into conflict with justice.

Andrzej Gomułowicz thinks similarly, stating that a judge must ponder over the uncritical adoption of the principle dura lex sed lex to prevent 'thoughtless and mechanical application of the law'. In the opinion of Gomułowicz, the exercising of the judicial powers by a judge is fascinating and responsible because in certain special and exceptional circumstances a judge can - during the process of applying law - 'im-

8 Niklas Luhmann, Das Recht der Gesellschaft (Frankfurt A. M.: Suhrkamp, 1993), 302.

9 Andrzej Gomułowicz, "Sędzia a 'poprawianie' prawa - zasadnicze dylematy," Zeszyty Naukowe Sądownictwa administracyjnego 1 (2012): 14. 
prove' the law. And this option provokes reflection, what arguments justify the judge's ability to 'correct' the law and how important is this 'improvement' of the law?

First of all, it should be noted that the judge has the power to administer the law, and in consequence, a judge gives the law a proper meaning in the process of its application, and thus the judge is responsible for the way in which the law is applied. The law must be an impassable borderline of taken actions by a judge of action, but is the law the same borderline for the judge if it is affected by qualified errors or defects due to the legislator's fault? Because of the essence and character of the exercised function, a judge has independent power, and in consequence he is free in his choices. Both the judge's independence and judge's intellect decides whether and how such a 'defective and imperfect law' will be applied by a judge. These features allow the judge to remain faithful to the 'idea of the law', even though in a given specific case the judge exceeds the 'borderline' of enacted law. A judge who 'corrects' the law is aware that he refers to those universal axiological values that must create an ethical order which is the foundation of the existence of the state. This is a difficult but responsible manner of activity of a judge, and this manner can also be derived from the functions that the judge performs.

An 'activated' judge assumes that universal axiological values (e.g. constitutionally protected values and goods) enable to create axioms that give an opportunity to deduce a coherent, rational set of rules of conduct in the interpretation process. Therefore, during the process of interpretation which aim is the development of law, a judge looks for a specific 'code of interpretation'. The Polish Constitutional Tribunal indicates that this code of interpretation may be the Constitution, as the Constitution in its entirety expresses a certain objective system of values, and the implementation of these values should be achieved by the process of interpretation and application of individual constitutional provisions, and during the process of interpretation of these provisions, you should strive to determine interpreted provisions in accordance with the axiology of our political system and legal system. As Gomulowicz rightly indicated, 'in principle, a judge faces the need to' correct 'the law when the legislator violates the standards of political and legal culture during the legislative process. In that case, the law posses qualified 
weaknesses, and therefore the judge helps to create the law, rather than to apply $\mathrm{it}^{10}$.

\section{DIRECT APPLICATION OF THE CONSTITUTION IN THE CONTEXT}

OF THE SO-CALLED PRO-CONSTITUTIONAL INTERPRETATION OF STATUTES. THE PROBLEM OF CO-APPLICATION OF THE CONSTITUTION

At present, the so-called pro-constitutional interpretation of acts appears more and more often in Polish jurisprudence, which is a special type of judicial activism, which striving to implementation of constitutional values, not only omits a literal interpretation of the provisions (it is not anything special yet) but modifies the content of the norm in such a way that, in fact, the norm created in the process of interpretation is the opposite of a norm created in the legislative process.

The problem of the pro-constitutional interpretation of statutes by the courts is a consequence of Article 8 in the Constitution of the Republic of Poland, which introduces the possibility of direct application of the Constitution. Provisions of Art. 8 sec. 2 of the Constitution of the Republic of Poland of April 2, 1997, are a constitutional novelty, as none of the previous Polish constitutions has contained a provision of a similar content. However, its absence did not prevent the doctrine and the judicature from formulating theses about the direct application of some constitutional provisions. However, entering the provision in the text of the basic law, requiring its direct application is purposeful, because it unequivocally excludes the thesis that the Constitution is not a normative act and that the provisions of the Constitution are addressed only to the legislator.

The principle of direct application of the Constitution is interpreted in such a way that "each body of public authority is obliged to take into account the content of the provisions of the Constitution, if it makes decisions (legislative, administrative, court judgments). They can, if they are sufficiently unambiguous, constitute an independent basis for such a decision" ${ }^{\prime 1}$.

10 Gomułowicz, "Sędzia a 'poprawianie’ prawa," 16.

11 Piotr Winczorek, Komentarz do Konstytucji Rzeczpospolitej Polskiej z dnia 2 kwietnia 1997 r. (Warsaw: LIBER, 2000), 20. 
The Supreme Court stated, that Art. 8 sec. 2 'obliges to apply the provisions of the Constitution directly, and the term 'application' must be primarily understood as judicial application of the law ${ }^{12}$. The Constitutional Tribunal stated that pursuant to Art. $8 \mathrm{sec} .2$ it is 'not only the obligation addressed, inter alia, to all bodies of public authority - to apply directly of the Constitution, but also the assumption of the possibility of such direct application, because such application is excluded only if the Constitution itself provides so. Therefore, there are no obstacles to the direct application of the Constitution by courts, but it should also be assumed that courts should use such direct application in all these situations, when it is necessary and possible 13 .

In the context of these considerations, it is important to discuss the socalled co-application of the Constitution because the basic forms of direct application of the Constitution are: the autonomous application of the Constitution (also called 'direct application') and the co-application of the Constitution together with statutes (also called 'not autonomous application'). The autonomous application of the Constitution means that the legal norm resulting from the Constitution is the only and sufficient basis for taking a decision by a court. It refers to the application of the Constitution in the form of individual and specific decisions (in particular court judgments), but also in abstract legal acts (laws, resolutions and other acts of public authorities). The only condition is that the provisions of the Constitution must be exact and unambiguous.

Co-application of the Constitution is a weaker version of 'direct application', but it is also the form most often used by courts. The Constitutional Tribunal thinks that 'wherever a legal matter is regulated at the same time by the Constitution and ordinary statutes, it is necessary to take these regulations into account'. It is about when the legal matter is regulated simultaneously, partly in the Constitution, and partly in an ordinary act. Co-application means the establishment of the proper sense of a norm on the basis of the Constitution, but giving priority to the ordinary act. The Constitution is then particularly important for the proper (pro-constitutional) interpretation of statutes. There are the fol-

12 PCT, Judgment of 7 April 1998, 90/98, OSNP 2000, no. 1, item 6.

13 PCT, Ruling of 22 March 2000, P 12/98, OTK ZU 2000, no. 2, item 97. 
lowing forms of application (co-application): ornamental (the court refers to a provision of the Constitution, despite the fact that the act provides a sufficient basis for solution of the legal matter); interpretative (establishes a legal norm taking into account both the norm of the act and the relevant norm of the Constitution; however, the Constitution may "co-create" a legal norm here); modifying (if it appears a conflict between the constitutional norm and statutory norms, the court eliminates it by interpretation using the conformity techniques to the Constitution, giving the legal norm a meaning justified by the supremacy of the constitutional norm.

Judicial activism, which is based on Art. $178 \mathrm{sec} .1$ of the Constitution of the Republic of Poland, authorizes the judge, pursuant to Art. 8 sec. 2 of the Constitution, to make a pro-constitutional interpretation of both the act and the regulation. It is one of the forms of direct application of the Constitution. Pursuant to Art. 178 of the Constitution, the framework of free judicial decisions is determined by the Constitution and statutes. Because judges are bound by the Constitution, they are also bound by its values. The idea of an equitable decision in the field of judicial application of the law is coherent with the ethos of the function of a judge and can be derived from the Constitution. In this context, it appears an obvious question about the limits of such a pro-constitutional interpretation.

The strongest reduction of judicial activism exists in the area of criminal law. The Supreme Court has repeatedly emphasized that 'relying on a pro-constitutional interpretation (...), especially in the area of criminal law, may not lead to such modification of the normative content of a given legal regulation, which would go beyond the possible, even the broadest, results of interpretation achieved on the linguistic level. Otherwise, the pro-constitutional interpretation would in fact replace the constitutional review of statutes, which is reserved for the Constitutional Tribunal under the Constitution'14. Therefore, the Supreme Court, by creation of such a view, refuses to apply non-linguistic methods to interpret an autonomous meaning, de facto recognizing that the pro-constitutional interpretation does not include the application of an extended interpretation. At the same time the Supreme Court, by formulating the objection to exceed-

14 Polish Supreme Court, Judgment of the of 5 December 2012, ref no. III KK 137/12 (LEX no. 1252713). 
ing the limits of the admissible interpretation clearly refers to the concentrated nature of the constitutional review of law in Poland.

The view of the Supreme Court may raise doubts, if this understanding of the pro-constitutional interpretation concerns only the interpretation of the criminal law or other branches of law, because if the Supreme Court uses the phrase 'in particular in the area of criminal law', it also allows for such interpretation in other areas of law. Another problem should be added to the above doubts. May a court, which recognizes any provision as inconsistent with the values resulting from the constitution, not apply such provision or should the provision be interpreted in such a way that it is consistent with the Constitution. It seems obvious that the courts takes the other view, which is confirmed by numerous jurisprudence of the Supreme Court ${ }^{15}$. According to the Supreme Court, 'The Court of Appeal is not authorized to adjudicate on the unconstitutionality of a given provision of the act. Only the Constitutional Tribunal has proper competence and only this Tribunal may consider removing provisions that are inconsistent with the Constitution from the legal system. Therefore, the court of general jurisdiction does not have the possibility to refrain from applying the binding provisions of the Act, invoking unconstitutionality of such provisions. The principle of direct application expressed in art. $8 \mathrm{sec} .2$ of the Constitution means the court's obligation to adjudicate in accordance with the priorities established in the Constitution. Therefore, courts are obliged to provide a pro-constitutional interpretation, but are not competent to adjudicate on the unconstitutionality of a provision and remove it from the legal system. In case of objections as to the compliance of a provision of the act with the Constitution, there is a special procedure under Art. 188 of the Constitution, which allows for removing of such a provision from the legal system. Any provision, which the Constitutional Tribunal has judged to be in conformity to the Constitution, can be applied and may constitute the basis for substantive court decisions'. Theoretically there is no problem up to this point. The problem begins when the court makes such a 'pro-constitutional' interpretation that is in direct contradiction to the wording of the provisions and turns its understanding 'upside

15 Polish Supreme Court, Judgment of the of 2 April 2009, ref no. IV CSK 485/08 (LEX no. 550930). 
down'. The problem exists because the court applies the provision theoretically, but at the same time you can have the impression that the provision is repealed, since it is not applied as the legislator directly assumed.

\section{PRO-CONSTITUTIONAL INTERPRETATION IN THE PRACTICE OF COMMON COURTS ON THE EXAMPLE OF THE APPLICATION OF THE PROVISIONS INTRODUCING THE ACT ON THE NATIONAL REVENUE ADMINISTRATION}

In this context, I would like to discuss the final judgment of the regional court in Legnica in a case related to the rearrangement of the National Revenue Administration ${ }^{16}$. The Act - the act introducing the Act on the National Revenue Administration ${ }^{17}$, hereinafter referred to as the 'r.i. NRA' took effect on November 16, 2016. On March 1, 2017, the Act of November 16, 2016 on the National Revenue Administration, entered into force ${ }^{18}$, hereinafter referred to as the 'Act on NRA'.

The provisions introducing the Act on the National Revenue Administration introduced three types of legal solutions concerning the change of the service relationship of the former Customs Service officers into a service relationship or an employment relationship in the Customs and Tax Service established in order to perform a reform of the whole tax administration.

The first solution can be defined as the continuation of the service relationship. The service relationship is continued when the competent authority submits a proposal to perform this service under new terms, in accordance with Art. $165 \mathrm{sec} .7$ in connection with art. 169 sec. 4 sentence 1 of r.i. NRA. However, the legislator clearly stipulates in the latter provision that the proposal to perform service in the Customs and Tax

16 Regional Court IV Labour Law and Social Security Department in Legnica, Judgment of 10 March 2020, ref. no. IV P 105/19, which was upheld by the District Court in Legnica, V Department of Labor and Social Security, judgment of October 14, 2020, ref. no. $\mathrm{V} \mathrm{Pa} \mathrm{28/20.}$

17 Act on introducing the Act on the National Revenue Administration of 16 November 2016, Journal of Laws, no. 1948 as amended.

18 Act on National Revenue Administration of 16 November 2016, Journal of Laws 2020, item 505 . 
Service has the form of an administrative decision determining the terms of the service.

The second solution assumes the expiration of the current service relationship. It expires as a result of not submitting an offer of further employment to the officer or non-acceptance of the offer of employment or service within the period specified by law (in accordance with Article 170 (1) (1) and (2) of the NRA). In such case, it takes place the expiration of the service relationship, which is treated as a dismissal from service. The basis of a decision concerning a dismissal from service is Art. 170 sec. 1 and 3 r.i. NRA in connection with Art. $276 \mathrm{sec} .1$ and 2 of the Act on NRA. Pursuant to that article, an administrative decision is taken out only in cases of transfer of an officer, the assignment of duties on another position, transfer to another position, suspension in performing official duties or dismissal from service. It should be added that the content of the above-mentioned provisions includes a closed list of the circumstances of the expiration of an officer's service relationship.

The third solution is the transformation of the current service relationship into an employment relationship as a result of submitting an employment offer to the current officer on the basis of an employment contract and its acceptance. The judgment under discussion concerned the third solution called 'giving civil status for the officers'.

According to Art. 167 paragraph. 7 r.i. NRA, the Director of the National Fiscal Information, the director of the Chamber of Tax Administration and the director of The Tax and Customs Academy, submit a written proposal specifying new terms of employment or service, which takes into account the qualifications and the course of previous work, or services, as well as the current place of residence to employees and officers, respectively, by May 31, 2017. This provision, therefore, describes the selection criteria under which competent authorities must take into account the qualifications of officers / employees and the course of previous work or service, as well as their current place of residence.

In this case, the court made several notices that may seem justified in light of the previous considerations about the role of the courts. The regional court emphasized that the settlement of each dispute by the court forces the judge to ask a series of questions: 'what provisions should be applied in the case', 'Where the provisions on which the decision was based 
were applied correctly', 'Was the interpretation of these provisions correct'. If the idea of the admissibility of verification of the correctness of the legislator's actions by a judge (by assessing, in the light of the Constitution or international law, the product of his work that we intend to apply in concreto) is approved - the list of questions that the judge must put to himself increases. You must also ask - at the moment when the following conclusion is reached: 'this provision so understood, is the basis for a decision' - whether the legislator, when issuing a provision of this content, could have done so, due to constitutional requirements and restrictions imposed on the norm-maker by international law, and also ask, whether he did it correctly, for example due to the axiological coherence of the system of sources of law (especially taking into consideration 'newer' sources and containing norms more representative for the axiology of the present, especially when they are included in acts being higher in the hierarchy of sources of law).

Therefore, courts are obliged (under the Article 178 of the Constitution in conjunction with Article 8 of the Constitution) to apply the Constitution (apart from statutes directly regulating the subject of the dispute), as well as international law which is legally binding in Poland. This type of perspective allows us to hope to increase judges' awareness that not only the 'regulation' which is the direct basis for resolving a specific dispute is 'important', but also the Constitution as a structural and axiological keystone of the legal system. Thus, in the court's opinion, narrowing the basis for a decision only to the provision on termination of the service relationship was constitutionally unacceptable.

According to the Regional Court in Legnica, 'finally, the problem is not direct application of the Constitution in a specific dispute as the basis of a decision, but encouraging to seek in it interpretative inspiration, code of understanding' of ordinary legislation by the Court, to change the concept of 'statute', which so far is interpreted by courts as a 'concrete basis for adjudication', beyond which the judge's power does not exist and the legality of a statute is not 'considered' by the judge, into the concept of 'statute' which is correct component of the legal system, consistent with and understood in accordance with the Constitution. Therefore, the reference in Art. 8 and art. 178 of the Constitution saying about subordination of courts to statutes and the Constitution and that they must 'remem- 
ber' about the existence of the fundamental statute, is an indication of the sources of judicial inspiration for legal interpretation. It is clearly indicated that the narrowly understood positivist idea of looking for the 'basis' of a decision is outdated, and the methods of understanding the text cannot ignore the systemic and axiological issues related to the Constitution'.

In the opinion of the Regional Court in Legnica, the act on NRA and the provisions introducing it must be assessed not only in the formal and linguistic level, but in the light of the substantial effects of this interpretation. The analysis of the effects of the act in the frame of the assessment whether the rules constructing legislative activities has not been infringed, indicates a breach of the principle of equality and leads to discrimination and unequal treatment of officers in a situation such as the plaintiffs. According to the court, the legal act (Act on NRA and r.i. NRA), actually performed goals other than those declared by the act, and thus the court restored the officers to service, recognizing that statutory provisions may not infringe constitutional values and should be understood in such a way to be consistent with these values.

Very interesting in the case is the fact that the regional court was totally committed to the intellectual legal discourse on judicial activism and, in justification of the sentence, it encouraged other courts to peculiar 'courage', hoping that the courts would abandon the positivist approach and base their judgments on the axiology of the Constitution. Instead, it is not easy to answer the question whether the 'pro-constitutional interpretation' of the act is still an ideology of a decision bound by law or an ideology of a free decision, or is it rather a search for a 'third way', assuming that court decisions should be based on the applicable law, but such attitude does not preclude valuation and evaluation within the limits set by the legislator, in this case the constitutional legislator.

\section{FINAL CONCLUSIONS}

Pursuant to Art. 8 sec. 2 of the Constitution of the Republic of Poland, provisions of the Constitution are applied directly, unless the Constitution provides otherwise. The essence of this regulation is the fact that a court or other body applying the law may take its decision directly on 
the basis of a specific provision of the Constitution, which will constitute the legal basis for a decision in an individual case. However, this does not mean a general right of courts to constitutional control of the legally binding acts, which, pursuant to Art. 188 of the Polish Constitution is the exclusive competence of the Constitutional Tribunal. At the same time, it is commonly believed that the presumptive compliance of a statute with the Constitution may be invalidated not only by the judgment of the Tribunal but also in the frame of the direct application of the Constitution by the courts. It does not mean that courts and other bodies have been granted the right to pronounce that some statutes are unconstitutional and to decide on this basis that they lost their binding force. It means only a control in exceptional circumstances, adcasum and effective inter partes, which results may be a refusal of application of law recognized by court as an unconstitutional regulation. Sometimes, however, the direct application of the Constitution leads to questions, whether the practice of the pro-constitutional interpretation of statutes applied by courts does not become a praeter legem practice, especially when the courts, despite a clear request of the party, decide not to submit a legal question to the Constitutional Tribunal.

\section{REFERENCES}

Banaszak, Bogusław. “Aktywizm orzeczniczy Trybunału Konstytucyjnego.” Przeglad Sejmowy 4 (93) (2009): 69-74.

Gomułowicz, Andrzej. "Sędzia a „poprawianie” prawa - zasadnicze dylematy." Zeszyty Naukowe Sądownictwa administracyjnego 1 (2012): 9-17.

Kuczma, Paweł. "O aktywizmie sędziowskim.” Zeszyty Naukowe Uczelni Jana Wyżykowskiego. Studia z Nauk Spotecznych 9 (2016): 187-197.

Luhmann, Niklas. Das Recht der Gesellschaft. Frankfurt A. M.: Suhrkamp, 1993.

Morawski, Lech. "Zasada trójpodziału władzy. Trybunał Konstytucyjny i aktywizm sędziowski." Przegląd Sejmowy 4 (93) (2009): 59-74.

Schlesinger, Arthur M., Jr. "The Supreme Court.” XXXV Fortune 73 (January 1947): 73-79.

Winczorek, Piotr. Komentarz do Konstytucji Rzeczpospolitej Polskiej z dnia 2 kwietnia 1997 r. Warsaw: LIBER, 2000.

Zajadło, Jerzy. “Nieposłuszeństwo sędziowskie.” Państwo i Prawo 1 (2016): 18-39. 
Zieliński, Maciej. “Derywacyjna koncepcja wykładni jako koncepcja zintegrowana.” Ruch Prawniczy, Ekonomiczny i Socjologiczny 3 (2006): 93-101.

Zieliński, Maciej, and Marek Zirk-Sadowski. "Klaryfikacyjność i derywacyjność w integrowaniu polskich teorii wykładni prawa." Ruch Prawniczy, Ekonomiczny $i$ Socjologiczny 2 (2011): 99-111. 
